\title{
High-titer expression of recombinant antibodies by transiently transfected HEK 293-6E cell cultures
}

\author{
Volker Jäger, Johanna Groenewold, Dominik Krüger, Dennis Schwarz, Veith Vollmer \\ From 24th European Society for Animal Cell Technology (ESACT) Meeting: C2P2: Cells, Culture, Patients, Products \\ Barcelona, Spain. 31 May - 3 June 2015
}

\begin{abstract}
Background
HEK 293-6E cells expressing constitutively a truncated version of EBNA-1 were originally developed at the NRC-BRI in Montreal, Canada. They already proved to be excellent tools for transient transfection and subsequent high-titer production of recombinant proteins [1]. We substantially improved an existing protocol by introducing a number of additional or alternative steps during and after transfection finally resulting in a high-titer production protocol suitable for routine manufacturing of $\mathrm{mg}$ to gram quantities of desired proteins.
\end{abstract}

\section{Experimental Setup}

A recombinant antibody construct introduced into an optimised plasmid vector was used as a model protein for all experiments [2]. A second plasmid for co-expression of an eGFP reporter gene was added at $5 \%$, totalling $1 \mathrm{mg} \mathrm{L}-1$ of plasmid DNA. Cultivation and transfection of HEK 293-6E cells was either done using FreeStyleTM F17 medium (Life Technologies) alone or in combination with SMIF8 $2 x$ (Scharfenberg SZS). Optimization experiments were performed in either shaker flasks, bench-top bioreactor systems (which could be operated also in continuous perfusion mode) or the BioLector $^{\circledR} 48$-well microbioreactor (m2p-labs). Transfection rates were monitored by co-expressed eGFP using a flow cytometer (GuavaEasyCyte) (as well as on-line by fluorescence measurement in the BioLector) and the antibody production by biolayer interferometry $\left(\right.$ Octet $^{\mathbb{R}}$ RED96; Pall fortéBIO). The concentrations of selected metabolites in the supernatant were measured photometrically (GalleryTM, Thermo microgenics).

Recombinant Protein Expression Group, Helmholtz Centre for Infection Research, 38124 Braunschweig, Germany

C 2015 Jäger et al. This is an Open Access article distributed under the terms of the Creative Commons Attribution License (http:// creativecommons.org/licenses/by/4.0), which permits unrestricted use, distribution, and reproduction in any medium, provided the original work is properly cited. The Creative Commons Public Domain Dedication waiver (http://creativecommons.org/publicdomain/ zero/1.0/) applies to the data made available in this article, unless otherwise stated. 


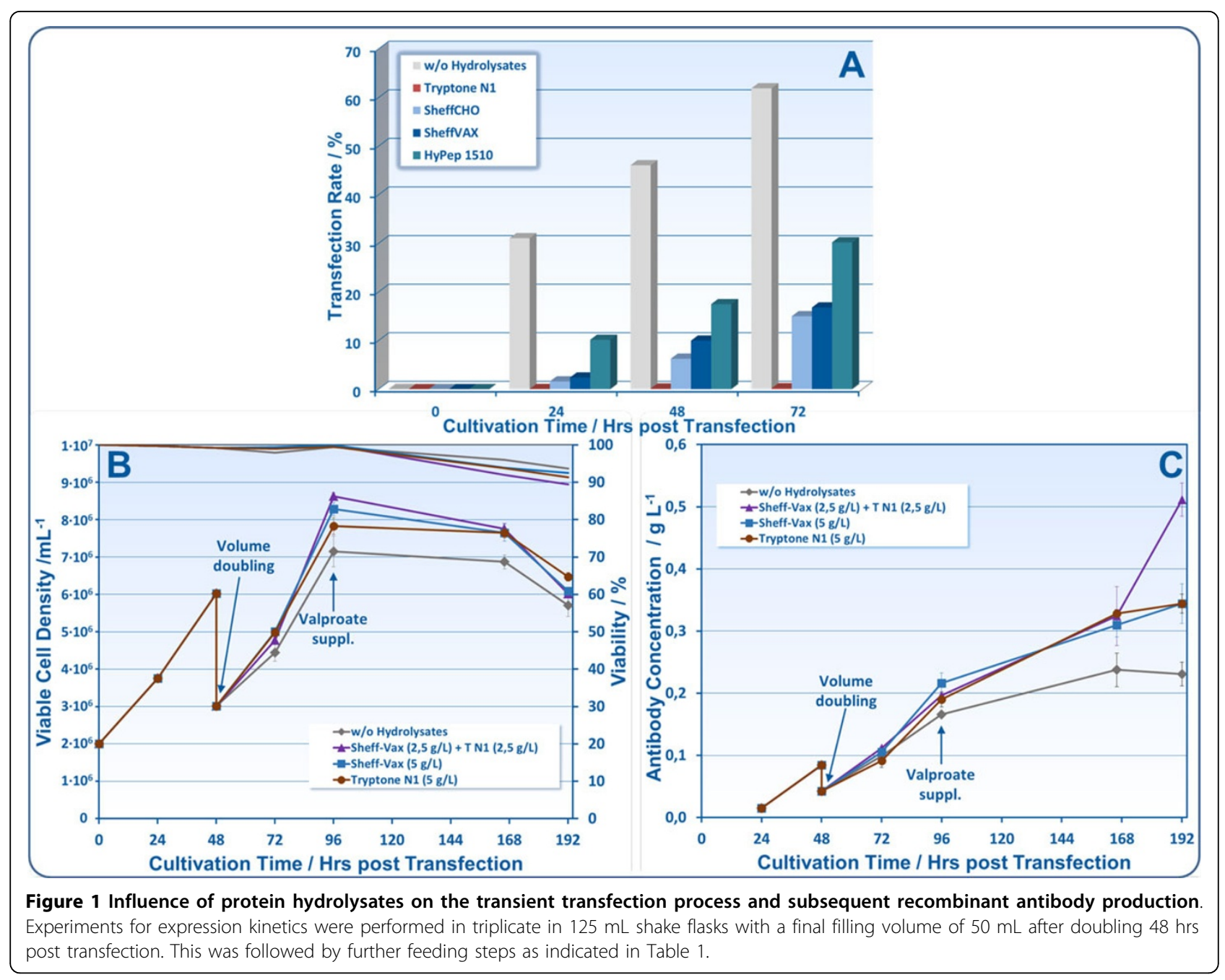

(Figure 1B) and substantially higher recombinant protein concentrations (Figure 1C). The cease of cell proliferation 96 hours post transfection was a result of sodium valproate supplementation. Accordingly, no nutrient limitations or inhibitory accumulations of metabolic byproducts were detected. Tryptone N1, manufactured from casein (Organotechnie), completely inhibited transient transfection of cells but, when supplemented 24 or $48 \mathrm{hrs}$ post transfection at a concentration of $5 \mathrm{~g} \mathrm{~L}-1$, increased recombinant antibody production. Similar results were obtained using different peptones (HyPep 1510, Sheff-Vax, Sheff-CHO, all from Kerry) with HyPep 1510 showing the lowest inhibitory effect during transfection and Sheff-Vax providing best productivity at $5 \mathrm{~g}$ L-1. A further increase in productivity was achieved by blending tryptone N1 with Sheff-Vax (at $2.5 \mathrm{~g} \mathrm{~L}-1$, respectively) which more than doubled the recombinant protein yield.

Correspondingly, the original transfection and protein production protocol was improved step by step by introducing alternative or additional steps of media supplementation and prolonging the cultivation process. Details of the resulting protocol are listed in Table 1.

\section{Conclusions}

Similar to the effect on many other cell lines both sodium butyrate and valproate substantially increase recombinant protein productivity of HEK 293-6E cells. However, cells do also respond with a reduced growth and finally a decline of viability which suggests a careful adjustment of both the concentration and the moment for HDACi supplementation. Combinations of both reagents did not reveal any cummulative effect. Thus, valproate was selected in order to minimise costs. Protein hydrolysates severely interfere with the process of cationic polymermediated transient transfection. However, when supplemented at a later stage, selected formulations ensure improved cell-specific recombinant protein productivity combined with a higher volumetric yield. On the contrary, many successful strategies reported for the cultivation of 
Table 1. Schedule for transient transfection of HEK 293-6E cells and subsequent feeding

\begin{tabular}{|c|c|c|c|c|}
\hline \multicolumn{3}{|c|}{ Original transfection protocol } & \multicolumn{2}{|c|}{ Improved standard transfection protocol } \\
\hline$-48 \mathrm{hrs}$ & Cell seed at $5 \cdot 10^{5} \mathrm{~mL}^{-1}$ or & $\downarrow$ & & \\
\hline-24 hrs & Cell seed at $1 \cdot 10^{6} \mathrm{~mL}^{-1}$ & & $-24-2$ hrs & Cell seed at $1-2 \cdot 10^{6} \mathrm{~mL}^{-1}$ \\
\hline $0 \mathrm{hrs}$ & PEl-mediated transfection & & 0 hrs & Cationicpolymer-mediated transfection \\
\hline 24-48 hrs & Tryptone feed (0.5\% TN1) & & & \\
\hline \multirow[t]{3}{*}{$48 \mathrm{hrs}$} & Harvest of intracellular proteins or & & $48 \mathrm{hrs}$ & Hydrolysates $(0.5 \%)+$ volume doubling \\
\hline & & & 72 hrs & Glucose feed $\left(4.5 \mathrm{~g} \mathrm{~L}^{-1}\right)$ \\
\hline & & & 96 hrs & Sodium valproate feed $\left(3.75 \mathrm{mmol} \mathrm{L}^{-1}\right)$ \\
\hline \multirow[t]{4}{*}{$120 \mathrm{hrs}$} & Harvest of extracellular proteins & & & \\
\hline & & & 144 hrs & or \\
\hline & & & 168 hrs & or \\
\hline & & & 192 hrs & Harvest of extracellular proteins \\
\hline \multicolumn{2}{|c|}{ Antibody yields in the range of 130 to $150 \mathrm{mg} \mathrm{L}^{-1}$} & & \multicolumn{2}{|c|}{ Antibody yields in the range of 500 to $800 \mathrm{mg} \mathrm{L}^{-1}$} \\
\hline
\end{tabular}

CHO cells proved to be unsuitable for HEK 293-6E. In addition, this cell line is also behaving quite different compared to other HEK 293 cell lines such as HEK 293 EBNA (formerly available from Life Technologies). By applying an improved transfection protocol the resulting final concentrations of recombinant antibodies could be increased by a factor of 4 to 5 and the yield based on the amount of used plasmid DNA by a factor 8 to 10 .

Published: 14 December 2015

\section{References}

1. Loignon M, Perret S, Kelly J, Boulais D, Cass B, Bisson L, Afkhamizarreh F, Durocher $Y$ : Stable high volumetric production of glycosylated human recombinant IFNalpha2b in HEK293 cells. BMC Biotechnol 2008, 8:65.

2. Jäger $V$, Büssow $K$, Wagner A, Weber $S$, Frenzel $A$, Schirrmann T: High level transient production of recombinant antibodies and antibody fusion proteins in HEK293 cells. BMC Biotechnol 2013, 13:52.

3. Wulhfard S, Tissot S, Bouchet $\mathrm{S}$, Cevey J, De Jesus M, Hacker DL, Wurm FM: Mild hypothermia improves transient gene expression yields several fold in Chinese Hamster Ovary cells. BiotechnolProg 2008, 24:458-465.

4. Øyaas $K$, Ellingsen TE, Dyrset $N$, Levine DW: Hyperosmotic hybridoma cell cultures:Increased monoclonal antibody production with addition of glycine betaine. BiotechnolBioeng 1994, 44:991-998.

5. Ye J, Kober V, Tellers M, Naji Z, Salmon P, Markusen JF: High-level protein expression in scalable $\mathrm{CHO}$ transient transfection. BiotechnolBioeng 2009 103:542-551.

doi:10.1186/1753-6561-9-S9-P40

Cite this article as: Jäger et al:: High-titer expression of recombinant antibodies by transiently transfected HEK 293-6E cell cultures. BMC

Proceedings 2015 9(Suppl 9):P40.

\section{Submit your next manuscript to BioMed Central} and take full advantage of:

- Convenient online submission

- Thorough peer review

- No space constraints or color figure charges

- Immediate publication on acceptance

- Inclusion in PubMed, CAS, Scopus and Google Scholar

- Research which is freely available for redistribution

Submit your manuscript at www.biomedcentral.com/submit
C BioMed Central 